Paper 2002-763

\title{
Why Settle for an MBA?
}

\author{
Ann Marie Flynn, Joseph Reynolds, Louis Theodore \\ Department of Chemical Engineering, Manhattan College, Riverdale, NY
}

\section{Introduction}

We engineers in education face a double challenge. First, many engineers move into management type positions within 5 years after graduation and utilize little to none of the technical material provided during their academic experience. They become what some have described as "paper shufflers". The second problem is an outgrowth of the first. The intelligent engineer, realizing the first problem, scuttles any plans for an advanced degree in engineering and instead moves on to a business/management-oriented graduate program, e.g., an MBA (Master of Business Administration). And, who can blame him/her? It obviously makes sense.

The displacement of engineers from traditional technical jobs is a reality that has been reinforced from discussions with hundreds of graduates from Manhattan College. Make no mistake and let us not be deceived. Only a handful are involved with detailed technical calculations and responsibilities. For us in chemical engineering, few are concerned with the design of a multicomponent distillation column, non-idea solution behavior, kinetic theory of chemical reactions, etc. The day of the high tech engineer is fast disappearing and has in a very real sense become a dying breed. And so, the clever engineer seeking an advanced degree looks elsewhere...usually in the direction of an institution offering an MBA. The degree is no longer unique to business majors; it is readily available to engineering majors. But, what is so special about the MBA mystique that it now belongs solely in the domain of the business schools? Surely, we engineers in education could do at least as good a job as our business educator counterparts...or perhaps even better. After all, ABET requires that engineering programs include some of the material offered in a typical MBA program, e.g., statistics, ethics, etc. This leads to the main thesis of the paper: engineering educators can provide programs and could very well better prepare engineers for a career in business /management.

Several faculty in the Department of Chemical Engineering at Manhattan College have discussed this situation at great length. The result: a proposed graduate program called "Masters Program in Engineering Management and Business Administration" (MEMBA). It is now widely accepted that the MBA is the ideal program for company executives, e.g., a CEO, but not for engineering managers. However, there are a lot more technical managers than CEOs ... and good project and program managers are difficult to come by. One authority who has been exposed to both an engineering and an MBA education recently commented: "For engineers who want to successfully rise through engineering management ranks, this (program) will be better than an MBA.” (1) 
Here is a bare outline of the program that is a modification of a plan developed by one of the authors (2) for another institution. (The reader should note that MEMBA has not been adapted by Manhattan College. It is simply a concept that was prepared by the authors without the influence of other related and/or similar programs, and is being offered to the engineering educ ation community).

\section{Program Overview}

The educational objectives of the MEMBA program are geared primarily to the engineer and the engineering profession. Its purpose is to further develop professional managers and prepare prospective managers for positions of administrative and business responsibilities, and to impart a knowledge and understanding of the resources required in management and business. The philosophy behind the choice of required courses (see next section) is based on the anticipated needs of a manager during his/her career.

Applicants are required to take the Graduate Management Admission Test (GMAT) and have their scores sent to the Director of the program. Applicants must possess a baccalaureate degree in an engineering program accredited by the Engineering Accreditation Commission of the Accreditation Board for Engineering and Technology (ABET) or from a recognized foreign institution. Students may be accepted as Applicant for Matriculation pending satisfactory completion of the GMAT. However, no more than six credits may be taken without satisfactory completion of the GMAT requirement. All students must ultimately complete thirty credits of course work to satisfy degree requirements.

Students may select one of several concentrations or options, including a "traditional" program that provides some flexibility involving elective courses. Specific course requirements and descriptions follow for the "traditional" program. Graduate courses taken in other programs require the approval of the Director. Course requirements and descriptions listed under the EBAG acronym (Engineering and Business Administration, Graduate) follow for the "traditional" program.

\section{Course Requirements and Descriptions}

\section{Required Courses (7,21 credits)}

EBAG.XXX Computer Simulation and Design. The use of simulation programs in the solution of engineering and business problems. Applications of contemporary computer software to increase speed, improve comprehension, and enhance presentation of results when analyzing, modeling and solving a wide variety of problems. (Three credits)

EBAG.XXX Project Management. Study of the content, planning, and control of a project. Comparison of functional management and project management, project organization structures, project planning, use of critical path methods and project control; emphasis on the project management concept and its applicability to a wide range of industrial projects. Extension of project management principles to program management. (Three credits)

"Proceedings of the 2002 American Society for Engineering Education Annual Conference \& Exposition Copyright@ 2002, American Society for Engineering Education” 
EBAG.XXX Project and Program Economics and Finance. Techniques for estimating investment and operating expenses. Profitability analysis, including depreciation and taxes in cash flow. Methods for comparing alternate investments. Market estimation and location efforts. (Three credits)

EBAG.XXX Unit Operations of Business - Accounting, Finance, Marketing Sales, Advertising and Distribution Principles. A general overview of accounting, administration, sales, marketing, distribution, advertising, manufacturing, inventory, and other business operations, including instruments to measure success. Human resources and relations, focusing on motivating and managing technical personnel. (Three credits)

EBAG.XXX Statistics. Basic theory and applications of principal components of statistics necessary for engineering and business problems. Probability theories, probability functions, statistical estimation, hypothesis testing, regression and correlation analysis, experimental design, statistical process control, limit of detection analysis. Introduction to analysis of variance (ANOVA). (Three credits)

EBAG.XXX Ethics and Business Law. Information about the environment of business contracts, legality, statute of frauds, remedies for breach, etc., plus engineering and business ethics. (Three credits)

EBAG.XXX Communications I. Course requirement includes the writing of a document suitable for publication as a guide, manual, chapter, or text under the supervision of a faculty mentor. The final project must be defended orally. Discussion of leadership qualities.

(Three credits)

\section{Elective Courses}

Business Course (at least one)

Engineering Course (at least one)

Communications II

\section{Conclusion}

The proposed "Master program in Engineering Management and Business Administration" (MEMBA), if implemented, can offer the engineer seeking a career in either management or business another option to the MBA. This new option may better prepare the engineer in future endeavors.

Other options are available in addition to the traditional course of study: one that concentrates on engineering management (EM) and one that concentrates on business administration (BA). EM would not require Ethics and Business Law; engineering courses would make up the remaining four courses that could include Communications II. BA would not require the Computer Simulation and Design; business courses would make up the remaining four courses that could include Communications II.

"Proceedings of the 2002 American Society for Engineering Education Annual Conference \& Exposition Copyright $\subset$ 2002, American Society for Engineering Education” 


\section{References}

1. Personal communication, 2002, Dr. John McKenna, PhD, President, ETS International

2. Personal notes, 2001, The Theodore Plan, L. Theodore

ANN MARIE FLYNN became the newest member in the Chemical Engineering Department at Manhattan College, when she joined the faculty in the Fall of 1996. She is also a graduate of Manhattan College, receiving her Bachelors degree in 1981 and her Masters in 1991. Both degrees were in Chemical Engineering. She received Ph.D. in Chemical Engineering from the New Jersey Institute of Technology in January, 2000.

JOSEPH REYNOLDS has a PhD in chemical engineering from Rensselaer Polytechnic Institute. He is a Professor of Chemical Engineering at Manhattan College and was Chairman of the Chemical Engineering Department from 1976 to 1983 . He has authored and coauthored numerous books and papers, mainly in the environmental area. He has 7 times been voted "Outstanding Teacher in the School of Engineering".

LOUIS THEODORE is Professor of Chemical Engineering at Manhattan College. Dr. Theodore is the recent recipient of the International Air and Waste Management Association's prestigious Ripperton award and the recipient of the American Society for Engineering Education (ASEE) AT\&T Foundation award for "excellence in the instruction of engineering students". 